\title{
The Teaching of English Idioms in Kenyan Secondary Schools: Difficulties and Effective Strategies
}

\author{
Moses Gatambuki Gathigia \\ Department of Languages, Karatina University, Kenya, P.O. Box 1957-10101, Karatina, Kenya \\ E-mail: gatambukimoses@gmail.com; mgathigia@karu.ac.ke \\ Martin C. Njoroge (Corresponding author) \\ Department of Communication, Languages and Linguistics, PAC University, P.O. Box 56875-00200, Nairobi, Kenya \\ E-mail: mnjoroge@pacuniversity.ac.ke; martin.njoroge@gmail.com
}

Doi:10.7575/aiac.alls.v.7n.2p.33

URL: http://dx.doi.org/10.7575/aiac.alls.v.7n.2p.33
Received: $12 / 11 / 2015$

Accepted: 07/01/2016

\begin{abstract}
The acquisition of idiomatic expressions is one of the primary challenges to learners of English as a Second Language (ESL) in multilingual contexts such as Kenya; yet, the learners are expected to use these expressions in their writing. The study on which this paper is based sought to assess the teaching of English idiomatic expressions in Kenyan secondary schools with a view to establishing the challenges teachers face in teaching the expressions and, thereafter, proposing effective strategies that can be applied for effective teaching of English idioms to ESL speakers. Ten teachers of English from both rural and urban secondary schools in Kenya were interviewed to find out the actual practices in their classrooms, the difficulties they face, and the effective strategies they employ for successful teaching of English idioms. The data collected were qualitatively analyzed. First, the study notes that it is possible to infer semantic relations between the literal sense of individual parts of an idiom and its meaning when interpreting compositional idioms. Second, there is incongruity between form and meaning when dealing with non compositional idioms since their semantic interpretation cannot be retrieved by means of their constituent parts. The study concludes that an understanding of the etymology of idioms can improve the comprehension and retention of idioms. The study recommends that idioms should be taught effectively in schools because the acquisition of idioms by learners will be an important indicator of their mastery of the English language.
\end{abstract}

Keywords: Idiomatic expressions, semantic relations, compositional idioms, non compositional idioms

\section{Introduction}

For many years, idiom instruction was viewed as a thorny issue by the vast majority of teachers in second language teaching contexts. The meaning of idioms was taken to be arbitrary, unpredictable and an alternative way of expression given the existence of literal equivalents (Irujo, 1993). However, despite the initial drawbacks, teachers and learners have come to accept the importance of idioms in language learning. In order to speak and write expressively, for example, a learner of any language must acquire the ability to use appropriate idioms. Idioms are inalienable part of a language that fall under the lexicon (lexis) of a language. It is important to note that the lexis is not limited to a repository of single words but it is a dynamic system, which includes larger lexical items [such as idioms] as well (Read, 2000).

Idioms play a pivotal role in both foundation and comprehension of every language since, among other things, idioms are an indicator of one's fluency in a particular language (Irujo, 1993). Nevertheless, as noted in the first paragraph of this paper, idiom learning constitutes a difficult part in second language acquisition because they are not always easily predicted from the literal meanings of their constituent parts. Strakšiene (2009), for example, notes this of idioms:

Idioms are considered to be one of the hardest and most interesting parts of the English vocabulary. On the one hand, they are considered one of the most peculiar parts of the language; on the other hand, they are difficult because of their unpredictable meaning and grammar (p.13).

Idioms, thus, require special attention in language teaching as they have been noted to be a challenge to teachers of English in a multilingual context (Baker, 1992; Boers, 2000; O’Dell, 2006). O'Dell (2006) specifically notes that the difficulties connected with teaching idioms can be avoided if suitable methods that make the learners more aware of potential problems in using idiomatic language are used. Consequently, good strategies will help learners avoid memorizing chunks of language which are soon forgotten (Boers, 2000; Gibbs, Bogdonovich, Sykes \& Barr, 1997). With this in mind, the main objective of this research, therefore, is to identify the difficulties faced in the teaching of 
English idioms in Kenyan secondary schools and recommend suitable strategies of teaching English idioms to ESL learners.

\section{Statement of the Problem}

English idioms constitute one of the most difficult linguistic aspects in second language acquisition because of their apparent incongruity between form and meaning. Moreover, the lack of explicit pedagogy of teaching English idioms mainly due to their figurative nature which consequently does not permit any lexical or syntactic modification poses a great problem to their acquisition. In contrast to syntax which has received a great attention, the study of idioms has also been neglected by educators and researchers, hence the need to give it attention. This paper, therefore, investigates the teaching of idioms in ESL contexts, specifically identifying the challenges faced in the teaching of English idioms and based on these challenges, recommends appropriate strategies for the teaching of English idioms in Kenyan Secondary schools.

\section{Rationale and Literature Review}

The choice of idioms as an aspect of linguistic study is based on a number of reasons. First, idioms are an integral part of language use and a reliable measure of the proficiency of foreign learners (Cowie, Mackin \& McCaig, 1983). Second, although literature materials ignore idioms entirely or relegate them to the 'other expressions' section of vocabulary lists, without providing exercises or other aids to learning (Irujo, 1986a, p. 237), idioms exhibit "idiom superiority effect." This means that idioms are easily identified by listeners as quickly as or even more quickly than typical expressions (Tabossi, Fanari \& Wolf, 2009) since they are generally a pervasive feature of many languages (Boers, 2000).

The motivation to study English idioms is based on the premise that English seems to be rich in multi-word lexemes like idioms (Anglin, 1993). In addition, according to Seidl and McMordie (1978), idiomatic usage is so common in English that it can be difficult to speak and write without using idioms. Therefore, since idioms are frequently utilized in spoken and written English discourse, language learners must make an effort to master idioms, though, according to Cooper (1999) and Irujo (1986b), complete mastery of the same may be nearly impossible. As Cooper (1998) notes, idioms require special attention in language teaching and learning and should not be relegated to a position of secondary importance in the curriculum.

\subsection{What is an Idiom?}

This research analyses several definitions of the term 'idiom' from various linguists. Moon (2006), for example, notes that an idiom is a multi-word item whose meaning is something else than the combined meanings of its constituent parts. Another linguist, Baker (1992), notes that idioms are "frozen patterns of language which allow little or no variation in form and often carry meanings which cannot be deduced from their individual components" (p.63). Closely related to the above definitions is Kovecses and Szabco's (1996) postulation that idioms are linguistic expressions whose overall meaning (figurative or idiomatic meaning) cannot be predicted from the meanings of the constituent parts (literal meaning). Carter (1987, p. 66) treats idioms as linguistic forms which can be defined as follows: they are nonsubstitutable collocations; they usually occur as more than single-word units and they exhibit semantic opacity and this is the definition adopted in the paper. The common thread in the above definitions is that idioms are larger lexical items whose meaning cannot be easily inferred from the components of the word and this is the perspective adopted in this paper.

\subsection{Research Studies on Idioms}

There are numerous studies of idioms across the globe which may be classified into two general classes: studies that focus on the learning of idioms in the first language (for example, Titone \& Connine, 1994) and studies of idioms in second / foreign language (for example, Cooper, 1999; Irujo, 1986a; Liontas, 2002). In Chinese, for example, Yang and Xie (2013) undertakes a study of 12 second-year Chinese learners who are engaged in a self-generated learning process that focuses on learning abstract and concrete idioms using iPads. The study found out that due to collaborative nature of this activity, iPads facilitated comprehension of idioms. Luk and $\mathrm{Ng}$ (1998) found that Computer Applied Language Learning (CALL) contributes to the learning of Chinese idioms. Specifically, the subjects aged 9-11 years, ranked graphic / drawing illustration as the second most effective strategy after explanation. Wong, Chin, Tan and Liu (2010) also found out that both the in-class and online sharing and discussions of the contexts enhanced the students' comprehension of the proper usages of the idioms.

In Turkish, Komur and Cimen (2009) investigate the effects of conceptual metaphors in the teaching of idioms in Turkey. The study notes that metaphor-related activities should be employed for idiom teaching. Lennon (1998) also supports this metaphorical approach. Kurt (1991) analyzes Turkish proverbs and idioms from a psychological perspective and shows that projection and displacement mechanisms are active in Turkish idioms, and that several proverbs indicate certain emotions.

Other studies which deal with the study of idioms from multilingual settings includes Irujo (1986a) who investigates whether advanced students of English rely on knowledge of their native Spanish in order to comprehend and produce L2 idioms. While idioms, which were similar in L1 and L2 presented learners with somewhat more difficulty, idioms that were completely different in L1 and L2 proved to be the most difficult for learners to comprehend and produce. Liontas (2002) examines the effect of context on the comprehension and interpretation of French, German and Spanish idioms which had been selected based on their interlingual similarity. Liontas (2002) reveals that context significantly 
affected the comprehension of idioms. The findings from these studies point to the need to document the experiences of teaching idioms in a multilingual setting such as Kenya to confirm if similar findings hold true.

\section{Research Methods}

\subsection{Research Design}

This study adopts a qualitative research design. The importance of using a qualitative research design is that it helps us understand the meaning of a phenomenon [in this study, idioms] from the perspective of the participants [in this study, the respondents] (Merriam, 1998). That is, a qualitative research 'says how things are' by informing the reader of phenomena as experienced by the study participants and interpreted by the researcher in a relevant context (Creswell, 2003); hence, the rationale of using this specific design.

\subsection{Sampling Procedure and Sampling Size}

Ten teachers of English in Nyeri County from both rural and urban secondary schools were purposively sampled for this study. This is consonant with Creswell (2008) advice about qualitative research that researchers may purposefully and intentionally select sites [respondents] that can best help them to understand their central phenomenon. The ten schools sampled are all categorized as District secondary schools in Nyeri County, Kenya.

\subsection{Data collection}

The study used an interview schedule as the tool of data collection (see Appendix 1). As Borg and Gall (1989) note, interviews are normally more flexible and are capable of producing data of great depth. Although an interview schedule follows a pre-determined structure, the researchers were able to ask probing questions to gain a fuller understanding of the issues under discussion (Gillham, 2005). The interview schedule (cf. Appendix 1) consisted of two sections. Section A helped the study in getting the bio-data of the respondents viz name (optional), age and the rural urban setting. Section B had three questions which helped the study get the teachers' opinions on whether idioms are an important part of English as a Second Language (ESL), identify appropriate strategies for teaching English idioms and the difficulties teachers experience while teaching English idioms (cf. Appendix 1).

\subsection{Data analysis and presentation}

Data analysis is the process of providing order, structure, and interpretation to collected data (Marshall \& Rossman, 1995). The data elicited through the interview schedule were coded and analyzed qualitatively. The results were then presented in tables and percentages summarizing the effective strategies employed in the teaching of English idioms and the difficulties faced in the teaching of English idioms (cf. Tables $1 \& 2$ ).

\section{Findings and Discussions}

Both the teachers of English from rural and urban settings had similar responses in relation to the questions in the interview schedule. The responses to each item are presented below:

Question 1: Do you consider idioms an important part of the English as second language teaching?

All the 10 teachers noted that idioms are an important and inalienable part of English as a second language. They explained that idioms have a great influence in the teaching and learning process of a second language since in order to speak and write succinctly, a learner must acquire the ability to use idiomatic expressions well. One teacher, however, added that idioms can be frustrating barrier to better understanding of English if not properly taught.

Question 2: If you were to teach idioms in your classroom, explain the strategies you would use to teach them? Give an example in English for every strategy you would employ in your teaching.

The research noted that there are a variety of strategies that teachers employ in the teaching of idioms. Table 1 below highlights some of the effective strategies employed by teachers in the teaching of English idioms and their percentage count.

Table 1. A summary of effective strategies employed in the teaching of English idioms

\begin{tabular}{llllll}
\hline \multirow{2}{*}{ No } & Strategy & \multicolumn{2}{c}{ No of Teachers for the strategy } & \multicolumn{2}{c}{ Percentage Count \% } \\
& & Rural & Urban & Rural & Urban \\
\hline 1 & Use of Context & 5 & 4 & 50 & 40 \\
2 & Discussion & 4 & 5 & 40 & 50 \\
3 & Etymology & 5 & 5 & 50 & 50 \\
4 & Grouping & 4 & 4 & 40 & 40 \\
5 & A Cognitive Approach & - & 1 & - & 10 \\
6 & A Compositional Approach & 5 & 5 & 50 & 50 \\
7 & Other Strategies & 2 & 2 & 20 & 20 \\
\hline
\end{tabular}


Strategy 1: The role of context in idioms learning

Nine teachers (five from rural and four from urban secondary schools) reported that for a better understanding of an idiom, teaching should always occur in a linguistically supportive context. A teacher suggested that the teaching of idioms should take place in a rich context for students' language learning and practice. One teacher from the rural setting noted that idioms should not be taught in isolation, but are best learned in a rich context as that gives the learners an opportunity to process them on a deeper level. Another teacher opined:

If a learner does not comprehend the appropriate context in which an idiom is used, he/she will use it inappropriately. This is because context facilitates the interpretation of figurative language by providing the necessary semantic information from which reader can infer the appropriate sense of expression.

This finding corroborates Thornbury's (2005) opinion that without context, language is not fully understood. Dunmore (1989) and Cooper (1999) also agree that using contextual clues to infer the meaning of unknown words is an effective strategy which helps learners acquire skills and aids vocabulary learning.

\section{Strategy 2: Group discussion}

Four teachers from rural and five from urban secondary schools noted that group discussions provide learners with rich opportunities to acquire social and linguistic knowledge necessary for understanding idioms that they encounter. The teachers argued that group discussions assist learners in the understanding of non decomposable idioms. A teacher explained her experience:

Every Tuesday and Thursday, I normally divide my class of 30 students into five groups of equal abilities and share five idioms I have selected for them to discuss. Each group discusses their meanings and constructs creative sentences which they present to the whole class. I listen to their presentations as I offer my critique to their presentations.

Another teacher emphasized that students were very excited in group discussion and recommended that putting students into group discussions is an effective way of teaching English idioms for various ages and levels.

\section{Strategy 3: The etymology of an Idiom}

All the teachers (five from rural and five from urban secondary schools) recommended that for effective teaching of idioms, the comprehension of the etymology of idioms is important. This is because, as one teacher noted, delving into the etymology of an idiom enhances retention and comprehension. Further, the association between an idiom and its etymology promotes insightful learning rather than 'blind' memorization thereby enhancing retention. This finding corroborates Boers, Demecheleer and Eyckmans (2004, p.53) postulation on etymological elaboration of idioms that "information about the origin of an idiom often enables learners to figure out their idiomatic meaning independently". For example, the idiom, "Pandora's box" has its origin from a character in Greek mythology who opened a box containing troubles and let the troubles come into the World (Rundell \& Fox, 2007). Another idiom like a "Sisyphean task" also has its etymology from the Greek myth in which Sisyphus was punished for the bad things he had done in his life. Sometimes, the Bible is needed to understand the etymology of an idiom. For example, "by the skin of one's teeth", will require one to understand its etymology. The idiom means "barely making it," "by a narrow margin" or "with nothing to spare." The idiom has its origins in the Bible, where Job is complaining about how illness has emaciated his body. He says: " ${ }^{20} \mathrm{My}$ bone clings to my skin and to my flesh, and I have escaped by the skin of my teeth." (Job 19:20). A teacher recommended that etymological elaboration of idioms should be employed in cases where there is incongruity between form and meaning when dealing with non compositional idioms since their semantic interpretation cannot be retrieved by means of their constituent parts. This is in consonance with studies which have confirmed the significant role of etymological elaboration in idiom comprehension (Bagheri \& Fazel, 2010; Boers, Demecheleer \& Eyckmans, 2004).

\section{Strategy 4: Grouping of idioms}

Four teachers from rural schools and four from urban secondary schools proposed that grouping of idioms assists learners in retrieving and organizing them in a more effective way. The teachers proposed that grouping of idioms may be based on thematic areas like idioms on emotions, Biblical idioms, idioms on farm animals, body part idioms et cetera. This corroborated McCarthy and O'Dell's (2008) opinion that idioms are connected with the themes of animals, the sea, sports, parts of the body, food and drink, colours, names of people and places, sight, hearing, taste, smell and touch. For example, a teacher can classify idioms which refer to farm animals, for example, "the black sheep of the family," "don't count your chickens," et cetera. Idioms from which body part represents a particular quality or ability, for example, "use your head," "the idea never entered my head," "she broke his heart," "he opened his heart," "I speak from the bottom of my heart," "the news finally reached her ears," "give / lend an ear," "split hairs," "keep your mouth shut, " "keep an eye on something." The following idioms may also be grouped together under the key word 'cards,': "Hold all the cards," "play your cards close to your chest," "lay all your cards on the table," "play your cards right" and "play your trump card". One of the teachers also gave the following experience:

"I arrange idioms according to their grouping. In one week for example, I teach idioms based on animals, like 'be like a cat on a hot tin roof,' 'cry like a baby', 'work like an ant' and 'red herring.' The following week after I am through with animal idioms, I may introduce another group of idioms based on emotions.

According to Schmitt (1997), grouping is an important strategy since it assists learners in retrieving and organizing vocabulary in a more effective way. 
Strategy 5: A Cognitive Linguistics view on idioms

One teacher from an urban secondary school proposed that the teaching of idioms should be based on the exploitation of the Cognitive Linguistics view on idioms. The teacher, paraphrasing Lakoff and Johnson's (2003) opinion, argued that one of the major tenets of Cognitive Linguistics is that metaphor is pervasive in our everyday life and that our conceptual system is metaphorical in nature. The cognitivist view suggests that the meaning of many idioms is not arbitrary, but it is motivated by metaphor, metonymy and conventional knowledge (Kövecses, 2002). The teacher proposed that learners should be trained on what motivates the usage of idioms as well as how to extrapolate the conceptual metaphors underlying the idioms in a given text. For example, when the idiom "spit fire" is used to express one's anger, one is unconsciously treating his or her body as a container full of emotions. Likewise, the idiom, "his ideas have finally come to fruition," falls under the conceptual metaphor, IDEAS ARE PLANTS since plants give rise to fruits. The Cognitive Linguistics technique, however, should be seen as a complementary means of instruction and not as the sole approach to teach figurative language for not all idioms are semantically motivated (Boers, 1999). An idiom like, "a snake in the grass," may be said to be based on A HUMAN BEING IS AN ANIMAL conceptual metaphor. The idiom, "hot under the collar," may be said to fall under ANGER IS HEAT/FIRE conceptual metaphor. This is in agreement with Lennon's (1998) suggestion that since idioms are so semantically opaque, they are well suited to a problem-solving approach in teaching, which can exploit learners' innate cognitive drive to make sense out of their environment.

\section{Strategy 6: The compositional analysis model}

Ten teachers (five from rural and five from urban secondary schools) underpinned the importance of a compositional analysis in the comprehension of idiomatic expressions. Teachers were unanimous that a compositional analysis is possible to infer semantic relations between the literal sense of individual parts of an idiom and its meaning when interpreting compositional idioms or decomposable idioms. Decomposable or compositional idioms are those whose figurative and literal meanings are close to each other (for example, "out of the woods," "hot potato," "walk on eggshells," "a bitter pill (for somebody) (to swallow)," and "rub salt into the wound," while the non-decomposable or opaque idioms are those whose literal meaning offers no clue for the construction on the figurative meaning (for example, "(buy) a pig in a poke," "dressed up like a dog's dinner," "to cleanse the Augean stables," "the black sheep," "bite the bullet, "pull a rabbit out of a hat"). This corroborates Penttilä (1998, p.158) argument that idioms can sometimes be understood from the constituent parts. Gibbs, Nayak and Cutting (1989) also agree that learners process decomposable idioms faster than non-decomposable idioms. So, in the teaching of idioms, a teacher should 'decompose' an idiom by looking at its literal meaning.

\section{Strategy 7: Other Strategies}

Four teachers (two from rural and two from urban secondary schools) also proposed the following strategies for the teaching of idioms in Kenyan secondary schools: matching of idioms with their meanings and the use of crossword puzzles. A teacher also argued that teachers should use idioms as a motivational tool by taking advantage of the entertainment factor to make the study of idioms easier.

Question 3: What are the difficulties you encounter while teaching idiomatic expressions?

The teachers identified the following difficulties that they encountered in the teaching of English idioms in Kenyan secondary schools. Table 2 below summarizes these difficulties:

Table 2. A summary of difficulties faced in the teaching of English idioms

\begin{tabular}{lllllc}
\hline No & Difficulty & \multicolumn{2}{c}{ No of Teachers } & \multicolumn{2}{c}{ Percentage Count \% } \\
& & Rural & Urban & Rural & Urban \\
\hline 1 & $\begin{array}{l}\text { Paucity of Suitable } \\
\text { Materials on Idioms }\end{array}$ & 6 & 4 & 60 & 40 \\
2 & Grammatical Errors & 4 & 5 & 40 & 50 \\
3 & Opacity of Idioms & 5 & 5 & 50 & 50 \\
4 & Attitudinal Problems & 4 & 4 & 40 & 40 \\
\hline
\end{tabular}

\section{Difficulty 1: Paucity of suitable materials on idioms}

Six teachers from rural and four from urban secondary schools noted that there is glaring paucity of suitable materials for teaching English idioms in Kenyan secondary schools. This corroborates Irujo's (1986a) observation that there is general lack of suitable materials for teaching idioms that makes it difficult for the learners to learn them. As such, teachers faced difficulties identifying the idioms to teach and suitable pedagogies. One teacher noted that he normally collects idioms for learners from newspapers, novels and other literary materials.

\section{Difficulty 2: Attitudinal Problems}

Eight teachers (four from rural and four from urban secondary schools) argued that students had attitudinal problems towards the learning of English idioms. A teacher recalled that a student had branded idioms as esoteric and difficult. 
He also claimed that students were apathetic to the teaching of idioms and, therefore, the teacher found it difficult to convince the learners that the teaching of idioms would enhance their writing and speaking skills.

\section{Difficulty 3: Grammatical errors}

Nine teachers (four from rural and five from urban secondary schools) noted that most idioms are relatively frozen and have severe grammatical restriction. As such, they do not permit any lexical or syntactic modification. This makes students to misuse idioms both while speaking and writing. A teacher noted of a case when a student formed a plural form for the idiom 'kick the bucket' to 'kicks the buckets.' Another teacher noted of a case when a student instead of using the idiom "a sacred cow," used an "evil cow." Therefore, teaching idioms and specifically, non decomposable idioms pose both grammatical and semantic challenges.

\section{Difficulty 4: Opacity of Idioms}

All teachers (five from rural and five from urban secondary schools) noted that learners of English as a second language experience greater difficulties learning the meanings of opaque idioms, than they do acquiring transparent ones. This is because the meaning of opaque idioms cannot be retrieved by means of the meaning of their constituent parts. For example, the idioms, "Pandora's box," "to kiss the blarney stone" and "pick up / take up the gauntlet" pose a great challenge to their comprehension.

\section{Implications}

The present study has implications for teachers, learners, the Kenya Institute of Curriculum Development and other stakeholders in education. First, the findings indicate that teachers sampled in the study use a number of strategies while teaching idioms because they understand the importance of mastery of idioms in language use. The findings could, therefore, persuade teachers of English in Kenya on the importance of teaching English idioms, and how to effectively teach them using the strategies highlighted in this paper. Specifically, the use of etymological elaboration is an effective strategy of teaching English idioms and especially when dealing with non compositional idioms. Second, the government and non governmental agencies need to support, finance and provide grants for the publication of literature on idioms since there is paucity of suitable materials on idioms. In addition, the Kenya Institute of Curriculum Development and other stakeholders in language learning and teaching should frequently organize workshops and seminars on the best and current strategies of teaching English idioms. The Kenya Institute of Curriculum Development should also consider giving idioms a more prominent role in second language learning by revising and modernizing the entire language education curriculum in Kenyan secondary schools.

\section{Conclusions}

The paper set out to investigate the teaching English idioms in Kenyan secondary schools, specifically focusing on the challenges teachers faced in teaching them and strategies used to alleviate these challenges. The findings reveal that idioms are an important part of English teaching and learning. The paper also notes that it is possible to infer semantic relations between the literal sense of individual parts of an idiom and its meaning when interpreting compositional idioms. Further, the paper points out that the strategy of delving into the etymology of English idioms is one of the most effective teaching strategies and especially so when idioms exhibit incongruity between form and meaning. The research also notes that there is paucity of literature on idioms, teachers are apathetic to the teaching of idioms, opaque idioms are difficult to comprehend and grammatical errors bedevil most learners' books. Despite these challenges, it is the recommendation of this paper that idioms should be taught effectively in schools because the acquisition of these idioms by learners will be important indicators of their mastery of the English language.

\section{References}

Bagheri, M., \& Fazel, I. (2010). Effects of etymological elaboration on EFL learners' comprehension and retention of idioms. Applied Linguistics, 14 (1), 45-55.

Baker, M. (1992). In other words: A course book on translation. London and New York: Routledge.

Boers, F. (1999). Learning vocabulary through metaphor awareness. Étudeset Travaux, 3, 53-65.

Boers, F. (2000). Metaphor awareness and vocabulary retention, Applied Linguistics, 21 (4), 553-571.

Boers, F., Demecheleer, M., \& Eyckmans, J. (2004). Etymological elaboration as a strategy for learning idioms. In P. Bogaards \& L. Batia (Eds.), Vocabulary in a second language: selection, acquisition and testing (pp. 53-78). Amsterdam / Philadelphia: John Benjamins Publishing Co.

Boers, F., Eyckmans, J., Kappel, J., Stengers, H., \& Demecheleer, M. (2006). Formulaic expressions and perceived oral proficiency: Putting a lexical approach to the test. Language Teaching Research, 10(3), 245-261.

Borg, W. R., \& Gall, M. D. (1983). Education research: An introduction (4 ${ }^{\text {th }}$ ed.). New York: Longman.

Borg, W., \& Gall, W. (1989). Educational research: An introduction. Toronto: Longman.

Cain, K., Oakhill, J., \& Lemmon, K. (2005). The relation between children's reading comprehension level and their comprehension of idioms. Journal of Experimental Child Psychology, 90, 65-87.

Carter, R. (1987). Vocabulary: Applied linguistic perspectives. London: Allen and Unwin.

Cooper, T. C. (1998). Teaching idioms. Foreign Language Annals, 31(2), 255-266. 
Cooper, T. C. (1999). Processing of idioms by L2 learners of English. TESOL Quarterly, 33(2), 233-262.

Cowie, A. P., Mackin, R., \& McCaig, I. R. (1983). Oxford dictionary of current idiomatic English: Phrase, clause and sentence idioms. Oxford: Oxford University Press.

Creswell, J. W. (2003). Research design: Qualitative, quantitative and mixed methods approaches (2 ${ }^{\text {nd }}$ ed.).Thousand Oaks, CA: Sage.

Creswell, J. W. (2008). Educational research: Planning, conducting, and evaluating quantitative and qualitative research. Ohio: Pearson.

Dunmore, D. (1989). Using contextual clues to infer word meaning: An evaluation of current exercise types. Reading in a Foreign Language, 6 (1), 337-347.

Gardner, R. C., \& Macintyre, P. D. (1991). An instrumental motivation in language study. Studies in Second Language Acquisition, 13(1), 57-72.

Gibbs, R. W. (1987). Linguistic factors in children's understanding of idioms. Journal of Child Language, 14, 569-586.

Gibbs. R. W. (1994). The poetics of mind: Figurative thought, language, and understanding. Cambridge: Cambridge University Press.

Gibbs R., Bogdonovich, J., Sykes, J., \& Barr, D. (1997). Metaphor in idiom comprehension. Journal of Memory and Language, 37, 141-154.

Gibbs, R. W., Nayak, N., \& Cutting, C. (1989). How to kick the bucket and not decompose: Analyzability and idiom processing. Journal of Memory and Language, 28, 576-593.

Gibbs, R. (2006). Embodiment and cognitive science, Cambridge: Cambridge University Press.

Gillham, B. (2005). Research interviewing: The range of techniques. Maidenhead, England: Open University Press.

Irujo, S. (1986a). A piece of cake: Learning and teaching idioms. ELT Journal, 40 (3), 236-242.

Irujo, S. (1986b). Don't put your leg in your mouth: Transfer in the acquisition of idioms in a second language. TESOL Quarterly, 20 (2), 287-300.

Keysar, B., \& Bly, B. M (1999). Swimming against the current: Do idioms reflect conceptual structure? Journal of Pragmatics, 31, 1559-1578.

Kömür, S., \& Çimen, S. (2009).Using conceptual metaphors in teaching idioms in a foreign language context. Sosyal Bilimler Enstitüsü Dergisi (LKE), 23, 205-222.

Kothari, C. (2004). Research methodology: Methods and techniques (2 ${ }^{\text {nd }}$ ed.). New Delhi: New Age International Publishers.

Kövecses, Z. (2002). Metaphor: A practical introduction. Oxford: Oxford University Press.

Kövecses, Z., \& Szabco, P. (1996). Idioms: A view from cognitive semantics. Applied Linguistics, 17(3), 326-355.

Kurt, İ. (1991). Türkatasözlerinepsikolojikbiryaklaşım. Ankara: Mas Press.

Lakoff, G., \& Johnson, M. (2003). Metaphors we live by. Chicago: University of Chicago Press.

Lennon, P. (1998). Approaches to the teaching of idiomatic language. IRAL, 36 (1), 11-30.

Liontas, J. I. (2002). Context and idiom understanding in second languages. EUROSLA Yearbook, 2, 155-185.

Luk, R. W. P., \& Ng, A. B. Y. (1998). Computer-assisted learning of Chinese idioms. Journal of Computer Assisted Learning, 14, 2-18.

Marshall, C., \& Rossman, G. (1995). Designing qualitative research. London: Sage Publications.

Merriam, S. B. (1998). Qualitative research and case study applications in education. San Francisco, Calif: JosseyBass.

Moon, R. (1997). Vocabulary connections: Multi-word items in English. In N. Schmitt \& M. McCarthy (eds.), Vocabulary: Description, acquisition and pedagogy (pp. 237-257). Cambridge: Cambridge University Press.

Moon, R. 2006. Vocabulary connections: multi-word items in English. In N. Schmitt and M.McCarthy (Eds.), Vocabulary: Description, acquisition and pedagogy (pp. 40 - 63). Cambridge: Cambridge University Press.

Nation, P. (2001). Learning vocabulary in another language. Cambridge, UK: Cambridge University Press.

Nunan, D. (2003). Practical English language teaching. New York: McGraw Hill.

O'Dell, F. (2006). Incorporating vocabulary into the syllabus. In N. Schmitt and M.McCarthy (Eds.), Vocabulary: Description, acquisition and pedagogy (pp. 258-278). Cambridge: Cambridge University Press.

Penttilä, E. (1998). Constructions and idiomatic expressions. Studies in Languages, 34, 157-167.

Perce, M. (2007). The Routledge dictionary of English language studies. London: Routledge.

Radden, G., \& Kovecses, Z. (1999). Towards a theory of metonymy. In K.U. Panther \& G. Radden (Eds.), Metonymy in language and thought (pp.17-59). Amsterdam / Philadelphia: John Benjamins Publishing Company.

Read, J. (2000). Assessing vocabulary. Cambridge: Cambridge University Press. 


Rundell, M., \& Fox, G. (2007). Macmillan English dictionary for advanced learners. London: Macmillan.

Saberian, N., \& Fotovatnia, Z. (2011). Idiom taxonomies and idiom comprehension: Implications for English teachers theory and practice in language studies, 1 (9), 1231-1235.

Scott, W., \& Ytreberg, L. (2000). Teaching English to children. New York: Longman.

Seidl, J., \& McMordie, W. (1978). English idioms and how to use them. Oxford: Oxford University Press.

Strakšiene, M. (2009).Translation strategies from English into Lithuanian. Studies about Languages, 14, 13-19.

Tabossi, P., Fanari, R., \& Kinou, W. (2009). Why are idioms recognized fast? Memory \& Cognition, 37 (4), $529-36$.

The Holy Bible, New King James Version (1982). Thomas Nelson, Inc.

Thornbury, S. G. (2005). Beyond the sentence: Introducing discourse analysis. Oxford: Macmillan Education.

Tompkins, G. E. (2001). Literacy for the 21st century (2 $2^{\text {nd }}$ ed.). Upper Saddle River, NJ: Prentice Hall.

Titone, D. A., \& Connine, C. M. (1994). Descriptive norms for 171 idiomatic expressions: Familiarity, compositionality, predictability, and literality. Metaphor and Symbolic Activity, 9, 247-70.

Wong, L.H., Chin, C.K., Tan, C.L., \& Liu, M. (2010). Students' personal and social meaning making in a Chinese idiom mobile learning environment. Educational Technology \& Society, 13 (4), 15-26.

Yang, C., \& Xie, Y. (2013). Learning Chinese idioms through iPads. Language Learning Technology, 17(2), 12-23.

Yoshikawa, H. (2008). International intelligibility in world Englishes: Focusing on idiomatic expressions. International Communication Studies, 17 (4), 219-226.

\section{Appendix 1: Interview schedule of teachers of English}

The purpose of this interview schedule is to get your views on the difficulties you face and the effective strategies you employ in the teaching of English idioms in Kenyan secondary schools. Any information that you give will be treated with confidence and will only be used for the purpose of this academic research.

\section{Section A}

Name (optional)

Age .

Your area of teaching

Rural ( ) Urban ( )

\section{Section B}

1) Do you consider idioms an important part of the English as second language teaching?

If YES - explain why:

If $\mathrm{NO}$ - explain why not:

2) While teaching idioms in your classroom, explain the strategies you would use you to teach them? Give an example in English for every strategy you employ in your teaching.

3) What are the difficulties you encounter while teaching idiomatic expressions? 